\title{
EFEKTIVITAS PELATIHAN SELF MANAGEMENT UNTUK MENINGKATKAN KEBAHAGIAAN PEKERJA SOSIAL DI LEMBAGA SWADAYA MASYARAKAT (LSM) YANG MENANGANI KASUS ANAK
}

\author{
Agustina Engry ${ }^{1}$ \\ Tri Kurniati Ambarini \\ agustina-engry@ukwms.ac.id \\ tri.ambarini@psikologi.unair.ac.id \\ ${ }^{1}$ Fakultas Psikologi Universitas Katolik Widya Mandala Surabaya \\ ${ }^{2}$ Fakultas Psikologi Universitas Airlangga Surabaya
}

\begin{abstract}
Abstrak
Penelitian ini bertujuan untuk mengetahui efektivitas pelatihan self management untuk meningkatkan kebahagiaan pekerja sosial di Lembaga Swadaya Masyarakat (LSM) yang menangani kasus anak. Penelitian ini termasuk eksperimen kuasi dengan jumlah subjek tujuh orang pekerja sosial yang berasal dari tiga LSM yang berbeda. Desain penelitian yang digunakan adalah single group pretest posttest design. Alat ukur yang digunakan adalah The Oxford Happiness Questionnaire dari Argyle dan Hills (2001) yang telah diadaptasi ke dalam bahasa indonesia. Analisa data menggunakan teknik Wilcoxon Signed Ranks Test dengan hasil sig 0,075 yang berarti tidak ada perbedaan yang signifikan antara skor kebahagiaan sebelum dan setelah diberikan pelatihan self management kepada pekerja sosial.
\end{abstract}

Kata Kunci: Self management, Subjective well being, Pekerja sosial, Lembaga Swadaya Masyarakat (LSM)

\section{Abstract}

The purpose of this research is to find out the effectiveness of self management training to increase happinesss on social workers that work in children social organization. This study used a quasi experimental research with seven social workers from three different Children Social Organization. The type of quasi experimental designs is single group pretest posttest design. Instrument that used is The Oxford Happiness Questionnaire from Argyle and Hills (2001) that has adapted to bahasa Indonesia. Data analysis used Wilcoxon Signed Rank Test with sig 0,075 that means there is not a significant difference happiness score before and after self management training given.

Keywords: Self management, Subjective well being, Social workers, children social organization

Indonesia merupakan negara keempat yang memiliki penduduk terbanyak di dunia. Jumlah penduduk yang banyak, tentunya juga disertai dengan banyak permasalahan sosial. Pada tahun 2015, jumlah Penyandang Masalah Kesejahteraan Sosial (PMKS) diperkirakan sebanyak 17,2 juta orang. Berdasarkan Peraturan Menteri Sosial Republik Indonesia nomor 16 tahun 2017 pasal 1 ayat 9, PMKS adalah seseorang/ keluarga yang mengalami hambatan dalam melaksanakan fungsi sosial dan tidak dapat memenuhi kebutuhan hidupnya (jasmani, rohani dan sosial) secara memadai. (Peraturan Menteri Sosial Republik Indonesia, 2017). Contoh PMKS adalah anak terlantar, anak yang memerlukan perlindungan khusus, korban tindak kekerasan, dll. Jumlah kasus sebesar itu tentunya membutuhkan beberapa tenaga untuk melakukan pendampingan terhadap mereka. Tenaga yang digunakan untuk melakukan 
pendampingan itu adalah para pekerja sosial. Jumlah pekerja sosial tersebut baru memenuhi $10 \%$ dari total yang dibutuhkan oleh masyarakat Indonesia (Yulianti, 2015). Data ini menunjukkan pekerja sosial di Indonesia memiliki tugas yang lebih berat karena jumlah kasus yang dihadapi sangat banyak dan belum diimbangi dengan jumlah tenaga yang tersedia. Pembahasan pekerja sosial pada penelitian ini berfokus pada orang yang melakukan kegiatan sosial secara sukarela dan tidak merupakan profesi yang mendapatkan keuntungan secara materi.

Profesi pekerja sosial di suatu Lembaga Swadaya Masyarakat (LSM) tentu memiliki sisi-sisi positif dan negatif sebagai resiko pekerjaan yang harus dihadapi. Terutama pekerja sosial yang bekerja di bidang yang melayani kesehatan karena akan sering berinteraksi dengan individu yang mengalami kejadian traumatis (Palm dkk, 2004). Menurut Whitaker (2004), sisi positifnya adalah pekerja sosial mendapatkan tantangan di tiap tugas pendampingan yang mereka jalani, sehingga profesi sebagai pekerja sosial tidak membosankan. Mereka juga memperoleh kepuasan tersendiri saat mampu membantu masyarakat yang membutuhkan. Sukmaningrum (2005) membahas dari perspektif yang lain. Ia mengungkapkan sisi negatif dari profesi pekerja sosial sosial yaitu mengalami Burnout (kelelahan fisik, emosional, dan mental akibat keterlibatan jangka panjang dengan hubungan interpersonal yang menuntut), Compassion Fatigue (kelelahan emosional yang dapat terjadi setelah perilaku yang konsisten dalam menyediakan empati dan pertolongan kepada individu yang mengalami gejala traumatis), Secondary Traumatic Stress (distres yang dialami oleh individu karena mengetahui dampak berat dari trauma yang dialami oleh orang lain) dan Vicarious Trauma (perubahan yang terjadi secara kumulatif di dalam diri terapis yang dihasilkan karena adanya keterlibatan empatik yang mendalam dengan klien yang mengalami kejadian traumatis). Beberapa hasil penelitian menunjukkan bahwa bidang yang digeluti pekerja sosial merupakan bidang kerja yang memiliki tingkat stres yang tinggi dengan tingkat turn over (mundur dari pekerjaan) yang juga tinggi (Graham \& Shier, 2010). Dampakdampak negatif tersebut dapat mempengaruhi kualitas hidup dan berpotensi untuk menurunkan kebahagiaan pekerja sosial.

Menurut Argyle (2001), kebahagiaan (happiness) adalah dimensi utama yang dialami manusia termasuk di dalamnya suasana hati yang positif, kepuasan dalam hidup, pemikiran yang positif seperti optimis dan self esteem. Kebahagiaan itu terdiri dari sekurang-kurangnya tiga faktor seperti kepuasan hidup, afek positif dan afek negatif. Argyle (2001) juga menyatakan bahwa kebahagiaan memiliki arti yang sama dengan istilah subjective well being, sehingga penggunaan kedua istilah ini dapat digunakan untuk menjelaskan hal yang sama. Pernyataan ini juga sesuai dengan pendapat Diener (1984) yang mengemukakan bahwa subjective well being sering disebut dengan istilah kebahagiaan. Snyder \& Lopez (2002) memaparkan pentingnya untuk melakukan intervensi untuk meningkatkan kebahagiaan. Manfaat dari meningkatnya kebahagiaan adalah merasa lebih bahagia. Orang-orang yang lebih bahagia akan cenderung lebih terlibat secara sukarela, memiliki sikap kerja yang lebih positif dan menampilkan lebih banyak karakter yang diinginkan. Dampak-dampak ini sangat diperlukan oleh pekerja sosial untuk semakin memotivasi mereka dalam memberikan kinerja yang maksimal.

Pekerja sosial yang telah memiliki tingkat happiness yang tinggi tidak berarti bahwa akan selalu merasa bahagia setiap saat. Adanya pendampingan terhadap kasus-kasus yang sulit dan melibatkan klien traumatis dapat menurunkan tingkat kebahagiaan mereka. Usaha untuk meningkatkan happiness berasal dan dilakukan dari dalam diri individu tersebut. Usaha untuk meningkatkan happiness itu, perlu dipelajari dalam bentuk intervensi yang memberikan ketrampilan-ketrampilan dalam diri pekerja sosial. Salah satu bentuk intervensi yang dapat dilakukan adalah self management. 
Pelatihan self management memiliki makna yang luas dan tidak hanya berfokus pada pengelolaan potensi diri namun juga secara emosi dan perilaku. Weiss (1999) juga mendefinisikan self management adalah kemampuan diri dalam mengendalikan pemikiran, mental dan perilaku individu. Enam kompetensi yang ada dalam Self management adalah keutuhan, keyakinan diri, kesadaran diri, hasrat, penghormataan/ penghargaan diri dan menghormati orang lain. Keenam kompetensi tersebut meliputi upaya dari diri sendiri dan meningkatkan hubungan dengan orang-orang yang ada di lingkungan sekitar. Menurut Myers (2015), kedua hal tersebut merupakan strategi untuk meningkatkan kebahagiaan individu. Oleh karena itu, ketrampilan self management dapat bermanfaat bagi pekerja dan juga membantu untuk meningkatkan kebahagiaan mereka.

Terdapat beberapa penelitian yang terkait dengan self management dapat meningkatkan kebahagiaan. Penelitian yang membahas peran self management dalam meningkatkan subjective well being di DKI Jakarta dilakukan oleh Takwin, Singgih dan Panggabean (2012). Hasil penelitian itu menunjukkan self management memiliki peran yang signifikan dalam meningkatkan kualitas hidup, kualitas pekerjaan dan hubungan sosial; dapat membantu individu mengatasi permasalahan psikologis dan memiliki hubungan yang positif terhadap subjective well being. Penelitian lain dilakukan oleh Putri (2014) mengenai self management abilities untuk meningkatkan subjective well being perempuan lanjut usia di panti werda. Hasil penelitiannya menujukkan bahwa intervensi self management ability dapat meningkatkan subjective well being.

Berdasarkan pemaparan yang telah dijelaskan di atas, dapat dilihat bahwa kesehatan mental pekerja sosial perlu mendapatkan perhatian. Profesi pekerja sosial adalah salah satu pekerjaan yang rentan menghadapi banyak tekanan dan dapat menurunkan kebahagiaan. Salah satu upaya untuk meningkatkan kebahagiaan mereka adalah melalui self management. Peneliti ingin mengetahui efektivitas dari pelatihan self management apakah dapat meningkatkan kebahagiaan dalam diri pekerja sosial yang bekerja di LSM yang menangani kasus anak. Kurangnya penelitian mengenai kesehatan mental pekerja sosial juga mendorong peneliti untuk membahas topik ini. Selama ini, penelitian pada pekerja sosial lebih banyak dilihat dari persepektif psikopatologis. Ini yang mendorong peneliti ingin memberikan perspektif psikologi positif dari profesi pekerja sosial sehingga dapat dilihat kekuatan dari diri mereka untuk menghadapi konsekuensi negatif yang mungkin timbul dari pekerjaan mereka.

\section{Metode Penelitian}

Penelitian ini menggunakan pendekatan kuantitatif. Jenis metode kuantitatif yang digunakan dalam penelitian ini adalah secara eksperimen. Penelitian eksperimen yang digunakan pada penelitian ini adalah eksperimen kuasi. Goodwin (2010) menjelaskan bahwa penelitian eksperimen kuasi berbeda dengan penelitian eksperimen yang murni karena tidak adanya kontrol variabel dan randomisasi dalam pemilihan sampel populasi. Hal ini sejalan dengan pernyataan Carter (2010) yang menyatakan bahwa eksperimen kuasi dilakukan saat peneliti tidak mampu melakukan manipulasi aspek dan kontrol kurang efektif dilakukan sehingga sulit dilakukan analisa kausalitas. Pada penelitian ini randomisasi sulit dilakukan karena jumlah populasi yang terbatas.

Desain penelitian yang digunakan dalam penelitian ini adalah single group pretest posttest design. Single group pretest posttest design merupakan jenis ekspresimen kuasi yang merupakan pengembangan dari posttest only design. Pada single group pretest posttest design, pengukuran diukur dua kali yaitu sebelum dan sesudah diberikan perlakuan. Hasil kedua pengukuran ini kemudian dibandingkan untuk melihat hasil dari intervensi yang diberikan (Jackson, 2009).

Variabel bebas dalam penelitian ini adalah pelatihan self management. Variabel tergantung pada penelitian ini adalah kebahagiaan. 
Keterangan:

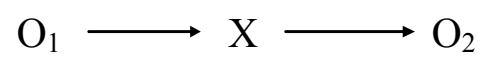

$\mathrm{X} \quad$ : Perlakuan (

$\mathrm{O}_{1} \quad$ : Pretest pada kelompok eksperimen

$\mathrm{O}_{2} \quad$ : Posttest pada kelompok eksperimen

Subjek penelitian ini ditentukan dengan cara non random sampling yang artinya kesempatan setiap individu populasi menjadi sampel adalah tidak sama (Zainuddin, 2011). Pemilihan sampel juga dilakukan dengan purposive sampling (pemilihan sampel berdasarkan kriteria yang telah ditentukan peneliti). Kriterianya meliputi pekerja sosial yang aktif bekerja di LSM anak, memiliki latar belakang pendidikan minimal SMA, hasil alat ukur (The Oxford Happiness Questionnaire) dengan total skor akhir berada di bawah 6 (skor maksimal) dan bersedia mengikuti keseluruhan proses pelatihan self management dari peneliti. Jumlah subjek penelitian adalah 7 orang.

Perlakuan yang diberikan berupa pelatihan self management yang modulnya disusun oleh peneliti dengan menggunakan teori Weiss (1999) dan Steverink (2005). Berdasarkan intisari kedua teori tersebut, dapat disimpulkan bahwa kemampuan self management meliputi tiga aspek yaitu kognitif (memiliki pemikiran yang positif, menyadari kekuatan dan kelemahan diri, yakin terhadap diri sendiri, mampu menghadapi permasalahan), emosi (memiliki hasrat/motivasi dalam diri dan memiliki self esteem) dan perilaku (pengembangan diri sendiri baik dari segi pengetahuan dan ketrampilan, melakukan kegiatan yang bermanfaat bagi masa depan dan menjalin hubungan yang baik dengan orang lain). Materi-materi itu dituangkan dalam 6 sesi. Pelaksanaan penelitian dilakukan secara bersama-sama sehingga peserta dapat saling berinteraksi dan berdiskusi. Setiap sesi menggunakan metode penyampaian yang berbeda-beda. Metode yang digunakan berupa ceramah singkat, diskusi, games, role play, tugas di rumah dan refleksi di setiap akhir sesi. Masing-masing sesi berlangsung selama 40-90 menit. Pelatihan self management ini dilakukan di Universitas Airlangga Surabaya. Penelitian ini tidak hanya memiliki data kuantitatif, namun juga secara kualitatif. Data kuantitatif diperoleh dari hasil alat ukur The Oxford Happiness Questionnaire, sedangkan data kualitatif diperoleh dari hasil tugas peserta di setiap sesi, hasil observasi masing-masing peserta selama pelatihan dan hasil wawancara follow up 3 minggu setelah pelatihan diberikan.

\section{Alat Ukur}

Alat pengumpulan data yang digunakan adalah The Oxford Happiness Questionnaire oleh Argyle dan Hills (2002). The Oxford Happiness Questionnaire dibuat oleh Michael Argyle dan Peter Hills pada tahun 2001. Alat ukur ini merupakan pengembangan dari The Oxford Happiness Inventory yang dibuat oleh Argyle, dkk pada tahun 1989. Alat ini disusun untuk mengukur tingkat kebahagiaan individu. Populasi yang digunakan untuk uji coba instrumen ini adalah 172 mahasiswa di Universitas Oxford Brookes beserta teman dan kerabat mereka. Usia mereka berkisar dari 13-68 tahun. Uji reliabilitas alat ukur ini sebesar 0,92 dan tergolong memiliki reliabilitas yang tinggi. Uji validitas yang digunakan adalah uji vaiditas konstrak. Dari hasil uji tersebut, nilai korelasi antara trait dan variabel kognitif sekitar 0,59-0,90. Terdapat hanya satu aitem yang tidak valid.

Alat Ukur OHQ ini menggunakan skala Likert 1 sampai dengan 6 pada setiap aitemnya. Nilai 1 sampai dengan 6 menunjukkan tingkat kesesuaian subjek terhadap masingmasing pernyataan, dimana 1 merupakan sangat tidak setuju sampai dengan 6 yang merupakan sangat setuju. Berikut merupakan kategorisasi tingkat kebahagiaan berdasarkan Wright (2008). 
Tabel 1

Kategorisasi Skor Akhir Kebahagiaan

\begin{tabular}{ll}
\hline Kategori & Skor Akhir \\
\hline Terlalu bahagia & 6 \\
Sangat bahagia & $5-6$ \\
Bahagia & $4-5$ \\
Netral & $3-4$ \\
Agak tidak bahagia & $2-3$ \\
Tidak bahagia & $1-2$ \\
\hline
\end{tabular}

Skala OHQ ini merupakan hasil adaptasi dari bahasa Inggris sehingga membutuhkan masukan dari ahli berupa professional judgement. Tujuan dari professional judgement adalah untuk memperoleh masukan terkait dengan kesesuaian hasil terjemahan yang telah dilakukan oleh peneliti.

\section{Metode Analisis Data}

Pengujian statistik yang digunakan untuk menganalisa data adalah Wilcoxon Signed Rank Test yang bertujuan untuk menguji perbedaan sampel berpasangan dalam satu kelompok yang sama (Carter, 2010). Pengujian ini paling sesuai digunakan untuk mengukur perbandingan antara skor sebelum dan setelah diberikan suatu intervensi. Seluruh analisa statistik pada penelitian dilakukan dengan menggunakan bantuan SPSS edisi 20. Hasil data kualitatif dianalisis dengan melihat proses dinamika proses perubahan dalam diri masingmasing peserta pelatihan secara keseluruhan baik dari saat dan setelah pelatihan.

\section{Uji Hipotesis}

\section{Hasil Penelitian}

Pengujian hipotesis dalam penelitian ini menggunakan teknik Wilcoxon Signed Ranks Test untuk melihat perbedaan skor kebahagiaan sebelum dan setelah mengikuti pelatihan self management. Hasilnya adalah sebagai berikut:

\section{Tabel 2}

\section{Hasil Perhitungan Statistik Wilcoxon Signed Ranks Test}

\begin{tabular}{lr} 
Test Statistica & $\begin{array}{c}\text { Pretest - } \\
\text { Posttest } \\
\text { Z }\end{array}$ \\
$\begin{array}{l}\text { Asymp. Sig. (2- } \\
\text { tailed) }\end{array}$ \\
$\begin{array}{l}\text { a. Wilcoxon Signed Ranks Test } \\
\text { b. Based on positive ranks. }\end{array}$ \\
\hline
\end{tabular}

Berdasarkan tabel 2 diperoleh nilai signifikansi sebesar 0,075 (sig 0,05) yang berarti hasil penelitian tidak signifikan. Dengan demikian dapat disimpulkan bahwa hipotesis penelitian ditolak menjadi tidak adanya perbedaan yang signifikan tingkat kebahagiaan pada pekerja sosial sebelum dan setelah diberikan pelatihan self management. 
Tabel 3

Skor Pretest dan Posttest Subjek

\begin{tabular}{|c|c|c|c|c|c|c|}
\hline Subjek & $\begin{array}{c}\text { Skor } \\
\text { Pretest }\end{array}$ & Kategori & $\begin{array}{c}\text { Skor } \\
\text { Posttest }\end{array}$ & Kategori & Selisih & Hasil \\
\hline 1 & 3,5 & Netral & 4,03 & Bahagia & $+0,53$ & Meningkat \\
\hline 2 & 4,4 & Bahagia & 5,3 & $\begin{array}{c}\text { Sangat } \\
\text { bahagia }\end{array}$ & $+0,9$ & Meningkat \\
\hline 3 & 4,41 & Bahagia & 4,48 & Bahagia & $+0,07$ & $\begin{array}{c}\text { Skor } \\
\text { meningkat } \\
\text { ketegori } \\
\text { tetap. }\end{array}$ \\
\hline 4 & 4,7 & Bahagia & 5,2 & $\begin{array}{c}\text { Sangat } \\
\text { bahagia }\end{array}$ & $+0,5$ & Meningkat \\
\hline 5 & 4,5 & Bahagia & 4,1 & Bahagia & $-0,4$ & $\begin{array}{c}\text { Skor } \\
\text { menurun, } \\
\text { kategori } \\
\text { tetap. }\end{array}$ \\
\hline 6 & 4,9 & Bahagia & 5,2 & $\begin{array}{c}\text { Sangat } \\
\text { bahagia }\end{array}$ & $+0,3$ & Meningkat \\
\hline 7 & 4,9 & Bahagia & 5,3 & $\begin{array}{c}\text { Sangat } \\
\text { bahagia }\end{array}$ & $+0,4$ & Meningkat \\
\hline
\end{tabular}

Berdasarkan tabel 3 dapat dilihat bahwa 6 orang subjek mengalami peningkatan skor (dimana 5 mengalami peningkatan kategori dan 1 tidak mengalami peningkatan kategori) dan 1 orang subjek mengalami penurunan skor, namun masih di kategori yang sama. Kenaikan rata-rata subjek berkisar 0,4. Subjek 3 mengalami kenaikan skor sedikit yakni 0,07 dan masih berada di kategori yang sama. Subjek 5 mengalami penurunan skor sebesar 0,4 dan masih berada di kategori yang sama.

\section{Dinamika Proses Individual}

Hasil kuantitatif yang diperoleh dan digunakan untuk menguji hipotesis menunjukkan bahwa hipotesis penelitian ditolak. Pelatihan self management tidak efektif dalam meningkatkan kebahagiaan pada pekerja sosial di LSM yang menangani kasus anak. Akan tetapi, jika dilihat secara proses individual terdapat perubahan dalam diri para subjek baik dari segi kognitif, emosi dan perilaku. Data ini diperoleh dari hasil tugas, observasi selama pelatihan dan hasil wawancara follow up terhadap semua subjek penelitian 3 minggu setelah proses pelatihan diberikan. Setelah Peneliti melakukan analisis data, maka peneliti melakukan evaluasi perubahan perilaku kepada seluruh subjek penelitian. Tujuan dilakukannya follow up adalah untuk mengetahui sejauh mana subjek penelitian menerapkan pembelajaran yang telah diterima dari pelatihan self management yang telah diberikan dalam kehidupan sehari-hari mereka. Data kualitatif ini sesuai dengan hasil kuantitatif per inidividu yaitu adanya peningkatan skor dan kategori kebahagiaan dalam diri subjek setelah pelatihan. Sejalan dengan ini, hasil follow up menunjukkan adanya hasil refleksi yang mendalam bahwa hasrat sangat dibutuhkan dalam menjalani profesinya sebagai pekerja sosial agar membantu dirinya untuk dapat mengatur dirinya. 


\section{Pembahasan}

Hasil penelitian menunjukkan bahwa dari hasil uji hipotesis yang dilakukan diperoleh kesimpulan bahwa tidak adanya perbedaan kebahagiaan yang signifikan pekerja sosial sebelum dan sesudah diberikan pelatihan self management. Penyebab dari signifikan atau tidaknya suatu statistik yang diuji tergantung dari ukuran sampel dan variabilitas data (Azwar, 2005). Pallant (2011) juga menyatakan bahwa pada penelitian eksperimen, jumlah subjek yang sedikit dapat mempengaruhi signifikansi suatu penelitian.

Dari ketujuh subjek yang mengikuti pelatihan, 6 subjek mengalami kenaikan skor kebahagiaan dan hanya 1 subjek (subjek 5) yang mengalami penurunan skor, namun masih berada di kategori yang sama. Ini dapat dijelaskan secara data kualitatif yaitu selama pelatihan ia terlihat paling pasif dan jarang berinisiatif untuk menyampaikan pendapatnya. Ini sesuai dengan pernyataan Hefferson \& Boniwell (2011) bahwa salah satu hal yang dapat meningkatkan kebahagiaan dalam diri individu adalah keaktifan. Keaktifan yang sederhana dapat memberi pengaruh pada fungsi kognitif dan emosi seseorang.

Hasil penelitian menunjukkan bahwa tidak adanya perbedaan yang signifikan kebahagiaan pekerja sosial sebelum dan sesudah diberikan pelatihan self management. Hasil ini dapat disebabkan oleh beberapa faktor. Salah satunya adalah jumlah subjek penelitian yang hanya berjumlah 7 orang. Selain itu, para ahli berpendapat banyak faktor yang dapat mempengaruhi kebahagiaan individu. Menurut Diener dkk (1999), kepribadian, tujuan hidup, kemampuan adaptasi dan coping dapat mempengaruhi tingkat kebahagiaan seseorang. Berdasarkan teori Layous \& Lyubomirsky dalam Myers (2015) menjelaskan bahwa kebahagiaan dalam diri individu sepenuhnya berada di bawah kendali masing-masing. Perlu adanya proses pemaknaan yang mendalam dari pengalaman yang telah dilalui. Mengingat waktu pengukuran yang singkat, maka proses pemaknaan yang dilakukan subjek belum maksimal.

Self management yang diberikan merupakan salah satu alat untuk memfasilitasi diri coping yang tepat untuk menghadapi pengalaman hidup masing-masing individu. Selain itu, ketrampilan yang telah diperoleh dari pelatihan membutuhkan waktu untuk dapat diaplikasikan ke kehidupan sehari-hari karena proses belajar tidak langsung menghasilkan perubahan secara cepat dan membutuhkan proses latihan yang berulang untuk memaksimalkan pembelajaran yang telah diterima (Olson \& Hergenhahn, 2013). Dari hasil observasi dan penugasan yang diberikan selama proses pelatihan menunjukkan bahwa subjek penelitian antusias dan mau terlibat aktif dalam kegiatan yang diberikan peneliti. Beberapa subjek telah melakukan materi pelatihan dalam kehidupan sehari-hari, namun pelaksanaannya belum konsisten.

Adapun beberapa keterbatasan dalam penelitian ini adalah sebagai berikut:

1. Jumlah subjek penelitian yang tergolong kurang sehingga hasil penelitian tidak dapat digeneralisasikan. Selain itu, ini juga dipengaruhi oleh ketersediaan subjek yang memenuhi kriteria peneliti tergolong kurang sehingga tidak memungkinkan untuk membentuk kelompok kontrol. Konsekuensinya adalah peneliti kurang mengetahui apakah perubahan skor posttest benar-benar disebabkan oleh pelatihan self management atau ada faktor lain yang mempengaruhinya.

2. Belum adanya alat ukur yang digunakan untuk mengukur kemampuan manajemen diri pada masing-masing subjek penelitian.

3. Pengukuran posttest yang dilakukan di akhir pelatihan sehingga kurang dapat mencerminkan hasil pembelajaran dan pemaknaan yang mendalam pada diri masingmasing subjek. 


\section{Simpulan}

Berdasarkan uraian di atas, maka dapat disimpulkan bahwa tidak adanya perbedaan kebahagiaan yang signifikan pada pekerja sosial sebelum dan setelah diberikan pelatihan self management. Meskipun secara statistik peningkatan skor tersebut belum signifikan. Data kualitatif yang diperoleh dari hasil tugas, observasi, wawancara menunjukkan adanya perubahan yang terjadi secara kognitif, emosi dan perilaku dalam diri masing-masing subjek peneliti di saat dan setelah mengikuti proses pelatihan manajemen diri.

\section{Saran}

Berdasarkan penelitian yang telah dilakukan, maka peneliti memberikan saran-saran sebagai berikut:

1. Bagi penelitian selanjutnya, dapat mengembangkan dengan menerapkan pada sampel yang berbeda dan dengan menggunakan kelompok kontrol dan eksperimen sebagai perbandingan hasil pelatihan. Selain itu, penelitian selanjutnya juga dapat dilakukan dalam jangka waktu yang lebih panjang untuk mengukur secara detail peningkatan kebahagiaan pada subjek penelitian.

2. Bagi subjek penelitian, dapat mengaplikasikan materi-materi yang telah diberikan selama proses pelatihan secara konsisten sehingga dapat bermanfaat terhadap peningkatan kebahagiaan dan kesehatan mental masing-masing subjek.

\section{Referensi}

Argyle, M., \& Hills, P. (2002). The oxford happiness questionnaire: a compact scale for the measurement of psychological well-being. Personality and Individual Differences, 33, 1073-1082.

Argyle, M. (2001). The psychology of happiness. New York: Routledge.

Azwar, S. (2005). Signifikan atau sangat signifikan? Buletin Psikologi UGM Vol. 13 (1), 110.

Carter, D. C. (2010). Quantitative psychological research: The complete student's companion $\left(3^{\text {rd }}\right.$ edition). New York: Psychology Press.

Diener, E. (1984). Subjective well-being. Psychological Bulletin, 95, 542-575.

Diener, E., Suh, E. M., Lucas, R. E., Smith, H. L. (1999). Subjective well-being: Three decades of progress. Psychological Bulletin, 125, 276-302.

Goodwin, C. J. (2010). Research in psychology: Methods and design. Danvers: John Wiley \& Son, Inc.

Graham, J. R. \& Shier, M.L. (2010). The social work profession and subjective well being: The impact of a profession on overall subjective well being. British Journal of Social Work, 40, 1553-1572.

Hefferon, K. \& Boniwell, I. (2011). Positive psychology: theory, research and applications. New York: Open University Press.Jackson, S. L. (2009). Research methods and statistics. California: Wadsworth.

Myers, D. G., \& Dewall, C. N. (2015). Psychology (11 $1^{\text {th }}$ edition). New York: Worth Publishers.

Olson, M. H., Hergenhahn, B. R. (2013). An introduction to theories of learning ninth edition. New York: Routledge.

Pallant, J. (2011). SPSS survival manual: a step by step guide to data analysis using SPSS $4^{\text {th }}$ edition. New South Wales: Allen \& Unwin.

Palm, K. M., Polusny, M. A., \& Follette, V. M. (2004). Vicarious traumatization: potential hazards and interventions for disaster and trauma workers. Prehospital and Disaster Medicine, 19 (1), 73-78.

Peraturan Menteri Sosial Republik Indonesia No. 16 Tahun 2017 Tentang Standar Nasional Sumber Daya Manusia Penyelenggara Kesejahteraan Sosial. 
Putri, P.K. (2014). Self management abilities untuk meningkatkan subjective well being perempuan lanjut usia di panti werda. Jurnal Ilmiah Mahasiswa Universitas Surabaya, $3,1-14$.

Snyder, C. R. \& Lopez, S. J. (2002). Handbook of positive psychology. New York: Oxford University Press, Inc.

Steverink, N., Lindenberg, S. L., Slaets, J. P J. (2005). How to understand and improve older people's self-management of wellbeing. Eur J Ageing, 10.

Sukmaningrum, E. (2005). Secondary traumatic stress (STS), vicarious trauma, dan burnout pada pendamping yang menangani kekerasan anak dan perempuan. Jurnal Psikologi, 15, 1-16.

Takwin, B., Singgih, E. E. Panggabean, S. K. (2012). The role of self management in increasing subjective well being of dki jakarta's citizens. Makara Sosial Humaniora, $16,1-8$.

Weiss, D. H. (1999). The self-management workshop. New York: American Management Association.

Whitaker, T. (2004). If you're right for the job, it's the best job in the world. Washington DC: Author.

Wright, S. (2008, 17 Oktober). Oxford Happiness Questionnaire.Newmeaninghappiness.com. Diakses dari http://www.new.meaningandhappiness.com/oxford-happinessquestionnaire/214/

Yulianti, T. E. (2015, 22 September). Belum ideal, pekerja sosial di indonesia masih satu berbanding seribu. Detik.com. Diakses dari http://news.detik.com/berita-jawabarat/3025569/belum-ideal-pekerja-sosial-di-indonesia-masih-satu-berbanding-seribu

Zainuddin, M. (2011). Metodologi penelitian kefarmasian dan kesehatan. Surabaya: Airlangga University Press 
Jurnal Experientia Volume 7, Nomor 1 Juli 2019 